\title{
Assessment of Ceruloplasmin, Hemopexin, and Haptoglobin in Asthmatic Children
}

\author{
Amany M. Abd Al-Aziz ${ }^{1}$, Hala Shaaban ${ }^{2}$, Ahmed A. Talaat ${ }^{1 *}$, Mona A. M. Awad ${ }^{3}$, Radwa Ali ${ }^{1}$, Walaa A. Shahin ${ }^{2}$ \\ ${ }^{1}$ Department of Pediatric, National Research Centre, Cairo, Egypt; ${ }^{2}$ Department Pediatric, Faculty of Medicine, Cairo University, \\ Cairo, Egypt; ${ }^{3}$ Department Clinical and Chemical Pathology, National Research Centre, Cairo, Egypt
}

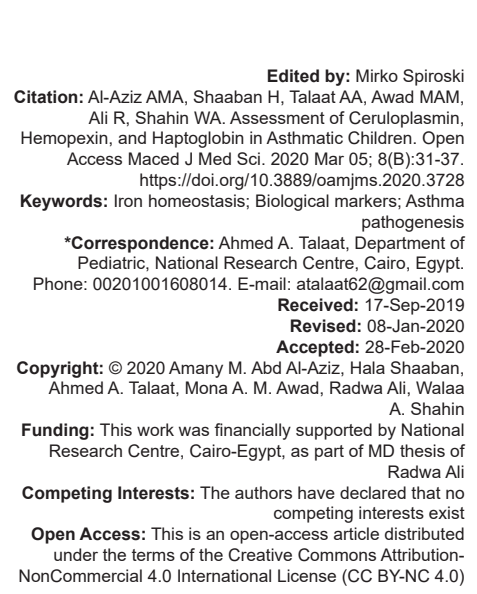

\section{Introduction}

Bronchial asthma has emerged as the most common non-communicable respiratory disease affecting children worldwide [1], and its prevalence is increasing. The causes and pathogenesis of bronchial asthma are not completely understood [1], [2], and it is becoming increasingly apparent that the disease is heterogeneous with respect to immune-pathology, clinical phenotypes, response to therapies, and natural history [3]. Precision in diagnosis and treatment has become imperative for the achievement of better outcomes [4]. In practice, a panel of biomarkers is needed to indicate the various underlying disease pathologies and enable the definitive categorization of asthmatics into distinct sub-phenotypes [5].

A potential for iron-catalyzed oxidative stress in asthma was reported [6], and proteomic discovery program has identified a panel of proteins indicating the involvement of iron metabolism pathway in asthma [7]. Ceruloplasmin $(\mathrm{Cp})$, haptoglobin, and hemopexin are predominantly liver-synthesized acute phase proteins that play a role in iron homeostasis and have important anti-inflammatory activity through inhibition of oxidative stress and iron sequestration resulting in antimicrobial activity [7], [8].

Cp regulates body iron homeostasis by its capacity to oxidize the highly toxic ferrous form of iron to the relatively nontoxic ferric form. $\mathrm{Cp}$ is required for efficient iron release from cells and tissues [9]. The inhibition of heme releases from globin by haptoglobin and sequestration of heme by hemopexin, suppress hemoglobin-mediated oxidative stress, attenuates endothelial cytotoxicity, and protects cells from heme toxicity [10].

These proteins may function to modulate the systemic inflammatory response to inflammation and be involved in tissue repair through fibrosis and angiogenesis [7]. We hypothesized that these proteins could be biological markers for bronchial asthma that reflect the involvement of iron in asthma pathogenesis and protect against iron oxidative stress. 
We aimed to evaluate the serum levels of proteins involved in iron homeostasis $(\mathrm{Cp}$, hemopexin, and haptoglobin) in asthmatic children and their correlation to pulmonary functions.

\section{Materials and Methods}

The study was case-control one, included 60 chronic asthmatic children aged $6-13$ years 30 recruited during attacks (Group I) and 30 recruited in-between attacks (Group II), they were recruited from Pulmonology and Allergy Clinic, Children's Hospital, Cairo University. Inclusion criteria: Patients suffering from asthma solely, based on careful history and physical examination as well as a documented reversible and variable airflow obstruction as described in GINA were included in the study [11]

\section{Exclusion criteria}

Patients with mild persistent or intermittent asthma, patients receiving inhaled corticosteroids or leukotriene antagonists within 1 week or receiving oral corticosteroids within 3 weeks before inclusion in the study, patients suffering from other chronic illnesses (diabetes mellitus, kidney disease, liver disease, or thyroid dysfunction), conditions that can alter acute phase reactants including patients with acute (within 1 week) and chronic inflammatory disorders, patients with neuromuscular disorders, patients with hemolytic anemia, Wilson's disease, lymphoma, and rheumatoid arthritis. Thirty non-atopic, non-asthmatic age- and sex-matched healthy control children (Group III) were also included. They were recruited from Ophthalmology Clinic, Children's Hospital, Cairo University. The study has been approved by the Ethical Committee of the National Research Centre. All patients' guardians gave informed written consent.

All candidates were subjected to detailed history taking, clinical evaluation, and assessments of pulmonary function tests (for patients). Venous blood samples were collected from all included children for the assessment of complete blood count, total serum $\lg \mathrm{E}$ level (using ELIZA DRG International Inc Kit (USA), and assessment of serum $\mathrm{Cp}$, hemopexin, and haptoglobin (using ELIZA assay pro Kits (Missouri, USA).

\section{Statistical analysis}

Data were analyzed using the GraphPad prism version 6. t-test was used to compare between two groups, and ANOVA test was used for comparison between more than two groups. For quantitative variables, mean, standard deviation was presented. Correlation to estimate the association between quantitative variables was presented in the form of correlation coefficient $(r)$ and its significance. $p<0.05$ was considered statistically significant.

\section{Results}

The study included 19 males (53.3\%) and 11 females (36.7\%) in Group I, 16 male (63.3\%) and 14 females (46.7\%) in Group II, no significant difference was detected ( $p=0.601)$ between both. Positive family history was present in 24 (80\%) of Group I and 15 (50\%) of Group II. Comparison between asthmatics (Groups I and II) and controls regarding demographic, clinical, and lab data are presented in Table 1.

The mean serum level of $\mathrm{Cp}$ exhibited significantly higher values in Group II compared to Group I ( $p=0.014)$ and in both Groups I and II, compared to controls ( $p=0.004$ and $p=0.0002$ respectively), Table 1 and Figure 1.

The mean serum level of haptoglobin exhibited higher values in Group II compared to Group I ( $p=0.006$ ) and control subjects ( $p<0.0001)$. The difference between Group I and control was insignificant ( $p=0.1$ ) (Table 1 and Figure 2).

The mean serum level of hemopexin exhibited higher values in Group I and Group II compared to control subjects ( $p=0.02,0.003$, respectively) but the difference between both Groups I and II was insignificant $(p=0.7)$, (Table 1 and Figure 2).

No significant correlations were found between any of the previous protein levels assessed and pulmonary functions or any other variable in the study, as presented in Table 2.

\section{Discussion}

Identifying biomarkers involved in asthma pathogenesis could have a possible role in bridging the diagnostic gap [4] and the creation of personalized treatment regimens [5]. The current study demonstrated differential expressions of $\mathrm{Cp}$, haptoglobin, and hemopexin among our clinical groups.

$\mathrm{Cp}$ is a sensitive acute phase reactant, which increases during acute and chronic inflammatory processes [12]. There is experimental evidence that some cell types in the lungs and airways may have the potential to produce $\mathrm{Cp}$ [13]. It has significant antioxidant capacity and can reduce lipid peroxidation 
Table 1: Demographic, clinical, and lab data of the studied groups

\begin{tabular}{|c|c|c|c|c|}
\hline Variable & $\begin{array}{l}\text { Group }(\mathrm{I}) \text { asthmatics during } \\
\text { acute attacks }(\mathrm{n}=30)\end{array}$ & $\begin{array}{l}\text { Group II asthmatics } \\
\text { between the attacks }(n=30)\end{array}$ & $\begin{array}{l}\text { Group III } \\
\text { controls }(n=30)\end{array}$ & $p$-value \\
\hline & Mean \pm SD & Mean \pm SD & Mean \pm SD & \\
\hline Age (years) & $9.5 \pm 2.366$ & $8.4 \pm 2.14$ & $8.96 \pm 2.01$ & $\begin{array}{l}0.08 \text { between Groups I and II } 0.97 \text { between Group III } \\
\text { and all asthmatics age }(8.977 \pm 2.34)\end{array}$ \\
\hline Age of onset of asthma (months) & $26.9 \pm 20.2$ & $22.6 \pm 18.3$ & & 0.4 \\
\hline Height $(\mathrm{cm})$ & $134.3 \pm 15.64$ & $128.5 \pm 14.81$ & $132.1 \pm 12.2$ & 0.14 \\
\hline Weight (kg) & $32.77 \pm 12.36$ & $29.07 \pm 10.6$ & $31.65 \pm 10.5$ & 0.21 \\
\hline Body mass index & $17.45 \pm 3.06$ & $16.8 \pm 2.4$ & $17.8 \pm 2.8$ & 0.4 \\
\hline Hemoglobin (g/dl) & $12.47 \pm 1.01$ & $13.4 \pm 1.3$ & $12.2 \pm 1$ & $\begin{array}{l}\text { Group I versus II }=0.002^{*} \\
\text { Group I versus control=0.4 } \\
\text { Group II versus control }=0.0003^{*}\end{array}$ \\
\hline Platelets $\times 10^{3} / \mathrm{ul}$ & $297.7 \pm 91.7$ & $289.2 \pm 81.5$ & $259.8 \pm 70.05$ & $\begin{array}{l}\text { Group I versus II=0.7 } \\
\text { Group I versus control=0.07 } \\
\text { Group II versus control=0.1 }\end{array}$ \\
\hline Leukocytic count $X 10^{3} / \mathrm{uL}$ & $11.5 \pm 4.14$ & $9.5 \pm 3.2$ & $6.2 \pm 2.5$ & $\begin{array}{l}\text { Group I versus II }=0.03^{*} \\
\text { Group I versus control }<0.0001^{*} \\
\text { Group II versus control }<0.0001^{*}\end{array}$ \\
\hline Absolute eosinophil count/cu mm & $833.67 \pm 351.09$ & $569.6 \pm 336.92$ & $135 \pm 34.63$ & $\begin{array}{l}\text { Group I versus II }=0.004^{*} \\
\text { Group I versus control }<0.0001^{*} \\
\text { Group II versus control }<0.0001^{*}\end{array}$ \\
\hline $\lg E(I U / m l)$ & $235.52 \pm 159.2$ & $125.64 \pm 149.9$ & $55.11 \pm 20.75$ & $\begin{array}{l}\text { Group I versus II }=0.007^{*} \\
\text { Group I versus control }<0.0001^{*} \\
\text { Group II versus control }=0.01^{*}\end{array}$ \\
\hline Ceruloplasmin (mg/dl) & $288.8 \pm 219.6$ & $448.04 \pm 386.79$ & $168.42 \pm 13.46$ & $\begin{array}{l}\text { Group I versus } \|=0.014^{*} \\
\text { Group I versus. control }=0.004^{*} \\
\text { Group II versus control }=0.0002^{*}\end{array}$ \\
\hline Haptoglobin $(\mu \mathrm{g} / \mathrm{ml})$ & $620 \pm 467.86$ & $993.33 \pm 554.56$ & $473.33 \pm 350.3$ & $\begin{array}{l}\text { Group I versus II }=0.006^{*} \\
\text { Group I versus control=0.1 } \\
\text { Group II versus control }<0.0001^{*}\end{array}$ \\
\hline Hemopexin $(\mu \mathrm{g} / \mathrm{ml})$ & $477.33 \pm 396.6$ & $509.33 \pm 341.51$ & $296.67 \pm 158.38$ & $\begin{array}{l}\text { Group I versus II }=0.7 \\
\text { Group I versus control }=0.02^{*} \\
\text { Group II versus control }=0.003^{*}\end{array}$ \\
\hline
\end{tabular}

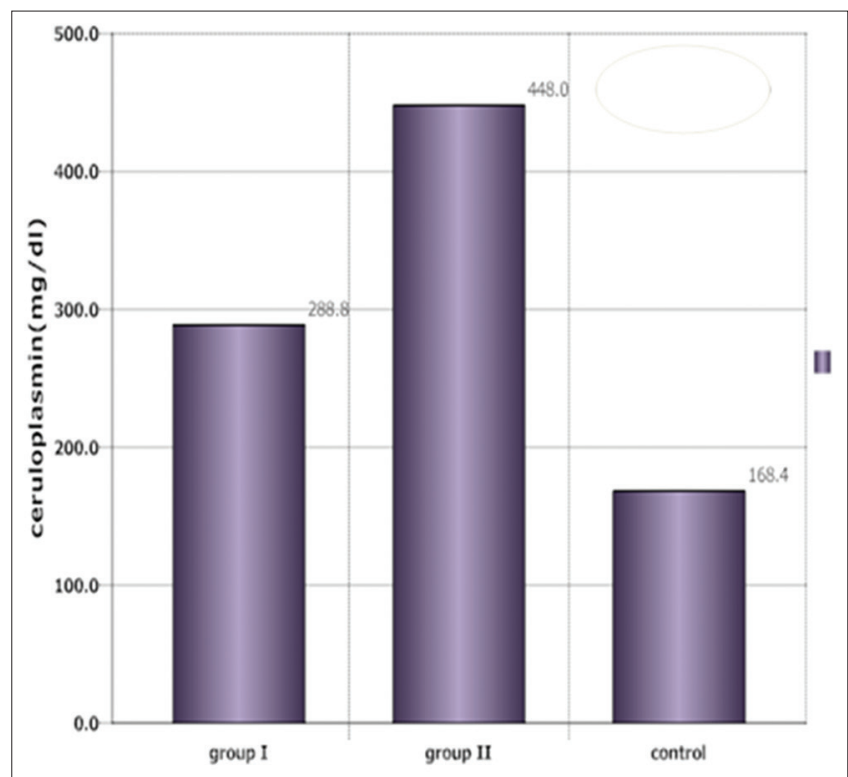

Figure 1: Comparison between mean serum levels of ceruloplasmin in Group I, Group II, and control children

induced by metal ions and peroxyl radicals, which in turn decreases cellular damage induced by toxic peroxidation products [14].

In our study, there was a significant higher $\mathrm{Cp}$ serum level in stable asthma and acute asthma exacerbation groups compared to controls. This agreed with Verrills et al. [7], Ermis et al. [15], and Vural and Uzun [16] who found significant higher $\mathrm{Cp}$ serum level in stable asthmatics compared to controls. Cp was significantly lower in acute asthma exacerbation when compared to stable asthma. This may be due to consumption during acute attacks for protection of the

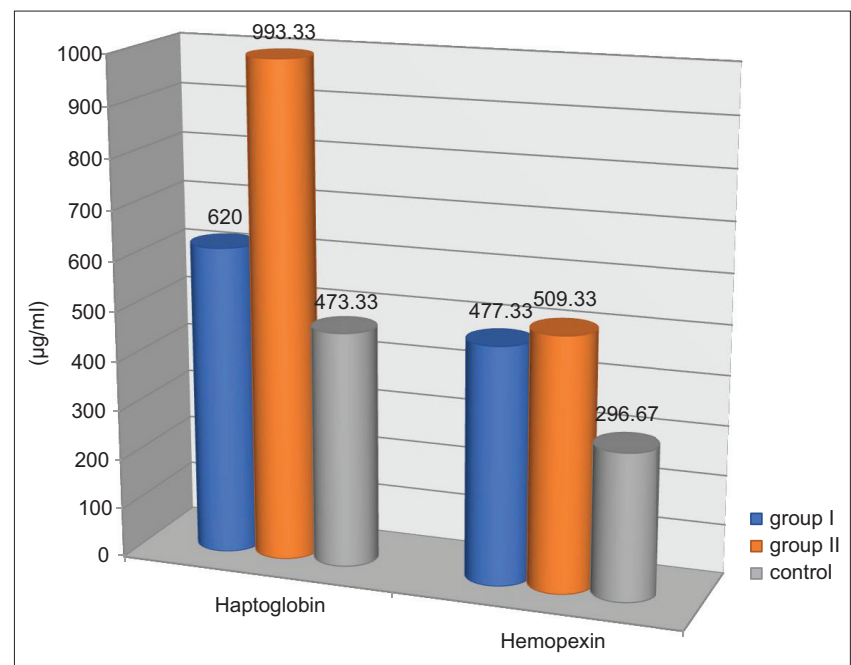

Figure 2: Comparison between Group I, Group II, and control subjects regarding mean serum levels of haptoglobin and hemopexin

lungs, as reported by Farkhutdinov and Farkhutdinov [17] who indicated that $\mathrm{Cp}$ use in the combination therapy of asthma exacerbation resulted in a reduction in reactive oxygen species generation and contributed to positive changes in the clinical symptoms of asthma. Another explanation is a possibility of leakage of this protein from the blood to tissue during acute exacerbations; this assumption was supported by Van Rensen et al. [18] who reported increased concentrations of $\mathrm{Cp}$ in the sputum of asthmatics 30 min following inhalation challenge with substance $P$ as compared to before the challenge; moreover, the sputum-to-serum ratios for $\mathrm{Cp}$ increased significantly after the challenge.

Haptoglobin is increased in alveolar macrophages and eosinophils in diseased or inflamed 
Table 2: Correlations between ceruloplasmin, haptoglobin, hemopexin, and different variables in asthmatic children

\begin{tabular}{|c|c|c|c|c|c|c|}
\hline \multirow[t]{2}{*}{ Variable } & \multicolumn{2}{|c|}{$\begin{array}{l}\text { Ceruloplasmin in } \\
\text { all asthmatics } \\
\mathrm{n}=60\end{array}$} & \multicolumn{2}{|c|}{$\begin{array}{l}\text { Haptoglobin in } \\
\text { all asthmatics } \\
\mathrm{n}=60\end{array}$} & \multicolumn{2}{|c|}{$\begin{array}{l}\text { Hemopexin in } \\
\text { all asthmatics } \\
\mathrm{n}=60\end{array}$} \\
\hline & $r$ & $p$ & $r$ & $\mathrm{p}$ & $\mathrm{r}$ & $\mathrm{p}$ \\
\hline Age (years) & -0.12 & 0.35 & -0.1 & 0.4 & -0.06 & 0.5 \\
\hline Age of onset of asthma & -0.07 & 0.5 & -0.11 & 0.3 & 0.21 & 0.1 \\
\hline $\lg E(I U / m l)$ & -0.01 & 0.9 & 0.06 & 0.6 & -0.02 & 0.8 \\
\hline $\begin{array}{l}\text { Absolute eosinophilia count } \\
\text { (cells/cu mm) }\end{array}$ & -0.0004 & 0.99 & -0.07 & 0.5 & 0.02 & 0.8 \\
\hline $\begin{array}{l}\text { Forced expiratory volume } 1 \% \\
\text { pred. }\end{array}$ & 0.13 & 0.32 & -0.2 & 0.1 & -0.02 & 0.82 \\
\hline Forced vital capacity $\%$ pred. & 0.15 & 0.25 & -0.24 & 0.06 & 0.019 & 0.88 \\
\hline $\begin{array}{l}\text { Forced expiratory flow } 25-75 \% \\
\text { pred. }\end{array}$ & -0.02 & 0.82 & -0.08 & 0.5 & -0.08 & 0.52 \\
\hline Peak expiratory flow \% pred. & -0.014 & 0.91 & -0.03 & 0.8 & -0.008 & 0.9 \\
\hline Haptoglobin $(\mu \mathrm{g} / \mathrm{ml})$ & 0.1 & 0.17 & & & & \\
\hline Hemopexin $(\mu \mathrm{g} / \mathrm{ml})$ & -0.1 & 0.43 & & & & \\
\hline $\begin{array}{l}\text { Correlation between haptoglobin } \\
\text { and hemopexin }\end{array}$ & & & 0.009 & 0.9 & & \\
\hline
\end{tabular}

tissues providing antioxidant and antimicrobial activity [19]. In our study, stable asthmatics exhibited significantly higher serum levels of haptoglobin compared to control subjects. This was consistent with the results demonstrated by Verrills et al. [7] and Kauffmann et al. [20]. The serum level of haptoglobin exhibited significant higher values in stable asthmatics compared to acute exacerbation. This agreed with Nishioka et al. [21]. Haptoglobin may be infused into the airways during the inflammatory process, which was supported by Larsen et al. [22]. Lamoureux et al. [23] have found that serum haptoglobin concentrations were significantly elevated in equine models of asthma during disease remission and after antigenic exposure compared to the control group. Variable serum levels of haptoglobin have been reported in asthma, either elevated [24], [25] or reduced [26]. Elevated haptoglobin in stable asthmatics (Group II) could be due to its involvement in tissue repair function [22] or to the kinetics of hepatic cellular response to cytokines [24]. The salivary concentrations of haptoglobin were found to be significantly higher in allergic asthmatic children [27].

A minor part of erythrocytes undergoes intravascular destruction, releasing hemoglobin which is bound by haptoglobin and the complexes is subsequently delivered to reticuloendothelial system, where they are internalized through receptor-mediated endocytosis. Haptoglobin, by binding hemoglobin and removing it from the circulation, prevents the ironstimulated formation of oxygen radicals and has an important role as an antioxidant [28]. Consistent with its role in modulating immune responses, haptoglobin at high levels was found to be related to AHR in asthma [25]. As part of its tissue repair function, haptoglobin can induce differentiation of fibroblast progenitor cells into lung fibroblasts and angiogenesis, potentially implicating haptoglobin in remodeling and fibrosis in asthma [22].

Hemopexin: In the current study, stable asthmatics exhibited higher mean serum levels of hemopexin compared to controls. This was consistent with the result of Verrills et al. [7]. Furthermore, we found higher serum levels of hemopexin during acute exacerbations compared to controls, which agreed with Haenen et al. [29] in murine models induced asthma. The serum level of hemopexin during acute exacerbations showed tendency to be lower than stable asthmatics, yet the change was statistically insignificant. This reduction may be justified by the expression of hemopexin in the airways, the same as haptoglobin do. Monferran et al. [30] have shown that the hemopexin domain of matrix metalloproteinase-9 (MMP-9) is important for the interactions of the metalloproteinase with the $\mathrm{Ku}$ heterodimer (Ku70/Ku80), a protein that plays a central role in DNA breaks repair. Interactions of Ku and MMP-9 have been reported to be involved in remodeling of the extracellular matrix, which is a major cause of airway remodeling in asthma and is closely related to airway wall fibrosis and airflow limitation [31]. Studies found that the plasma level of total MMP-9 was significantly increased in patients with asthma in acute exacerbation and decreased in remission but remained elevated compared to healthy controls [32], [33]. These data suggest that hemopexin may be consumed during asthma exacerbation being an important factor for the activity of MMP-9.

The reduction in serum haptoglobin level during exacerbation compared to stable asthma was more noticeable than the reduction in hemopexin; this may be explained by the fact that only once haptoglobin is depleted, do levels of hemopexin begin to fall as reported by Muller-Eberhard etal. [34]. When the buffering capacity of haptoglobin is exceeded, hemoglobin liberates heme, which binds to albumin and is subsequently transferred to hemopexin [35]. Hemopexin binds heme with high affinity and delivers it to the liver to provide protection against free heme-mediated oxidative stress and to limit access by pathogens to heme. This contributes to iron homeostasis by recycling heme iron [36]. Free heme is highly toxic as it is a source of redox-active iron. In the cytoplasm, iron can participate in the Fenton reaction to produce the highly toxic reactive oxygen species that damage lipid membranes, proteins, and nucleic acids [37]. Significantly increased levels of hemopexin and haptoglobin, in broncho-alveolar lavage fluid of asthmatic patients compared to control subjects was reported [38].

No correlations were detected in the present study between the levels of $\mathrm{Cp}$, haptoglobin, and hemopexin serum markers in all asthmatic patients and age. This agreed with Verrills et al. [7]. Serum Cp, haptoglobin, and hemopexin were not correlated to each other or to other different variables in the study (sex, age of onset of asthma, total serum $\mathrm{lgE}$, and total eosinophilic count). Similarly, no correlation was found between $\mathrm{Cp}$, haptoglobin, hemopexin, and lung functions. Vural and Uzun [16] demonstrated similar results concerning $\mathrm{Cp}$.

Higher serum total leukocytic count was demonstrated during acute exacerbations and stable asthmatics compared to control subjects. These 
observations were agreed with Galez et al. [39]. Razi et al. [40] had similar data regarding acute exacerbation. Significantly elevated total leukocytic count during asthma exacerbation compared to stable asthma was found; this agreed by Belda et al. [41]. This confirmed an association between systemic inflammation and airway inflammation, as previously shown in different studies [42], [43]. Leukocytosis may also happen due to long-term use of $\beta$-agonist or steroid use [44].

Hemoglobin concentration was significantly higher among stable asthmatics compared to acute exacerbation group but no significant difference between acute exacerbation and control groups. These results are consistent with the findings of a study done by Weiss and Desforges [45]. Hemoglobin was significantly higher among stable asthmatics group compared to control which agreed with Guo et al. [46], Hailemaryam et al. [47], and Ejaz et al. [48] and might be due to increased erythropoietin production induced under hypoxic conditions [49]. The reduction of $\mathrm{Hb}$ concentration during exacerbation may be due to the release of hemoglobin and its derivative heme into tissue compartments where there are infection and inflammation [10].

\section{Conclusion}

Cp, haptoglobin, and hemopexin can be used as a panel of non-invasive biomarkers that reflect involvement of iron oxidative stress in asthma pathogenesis.

\section{References}

1. World Health Organization. Asthma Key Facts. Geneva: World Health Organization. Available from: https://www.who.int/ respiratory/asthma/en.

2. D'Amato G, Salzillo A, Piccolo A, D'Amato M, Liccardi G. A review of anti-IgE monoclonal antibody (omalizumab) as add on therapy for severe allergic (lgE-mediated) asthma. Ther Clin Risk Manag. 2007;3(4):613-9. https://doi.org/10.2174/1568010043343615 PMid:18472983

3. Wenzel SE. Asthma: Defining of the persistent adult phenotypes. Lancet. 2006;368(9537):804-13. https://doi.org/10.1016/ s0140-6736(06)69290-8

PMid:16935691

4. Uwaezuoke SN, Ayuk AC, Eze JN. Severe bronchial asthma in children: A review of novel biomarkers used as predictors of the disease. J Asthma Allergy. 2018;11:11-8. https://doi. org/10.2147/jaa.s149577 PMid:29398922

5. Wadsworth S, Sin D, Dorscheid D. Clinical update on the use of biomarkers of airway inflammation in the management of asthma. J Asthma Allergy. 2011;4:77-86. https://doi.org/10.2147/ jaa.s15081

\section{PMid:21792321}

6. Mumby S, Chung KF, McCreanor JE, Moloney ED Griffiths MJ, Quinlan GJ. Pro-oxidant iron in exhaled breath condensate: A potential excretory mechanism. Respir Med. 2011;105(9):1290-5. https://doi.org/10.1016/j.rmed.2011.03.021 PMid:21514132

7. Verrills NM, Irwin JA, He XY, Wood LG, Powell H, Simpson JL, et al. Identification of novel diagnostic biomarkers for asthma and chronic obstructive pulmonary disease. Am J Respir Crit Care Med. 2011;183(12):1633-43. https://doi.org/10.1164/ rccm.201010-1623oc PMid:21471098

8. Fink MP. Editorial: Hemopexin: Newest member of the antiinflammatory mediator club. J Leukoc Biol. 2009;86(2):203-4. https://doi.org/10.1189/jlb.0309137

PMid:19643739

9. VassilievV,HarrisZL,ZattaP.Ceruloplasminin neurodegenerative diseases. Brain Res Brain Res Rev. 2005;49(3):633-40. https:// doi.org/10.1016/j.brainresrev.2005.03.003 PMid:16269323

10. Lin T, Kwak YH, Sammy F, He P, Thundivalappil S, Sun G, et al. Synergistic inflammation is induced by blood degradation products with microbial toll-like receptor agonists and is blocked by hemopexin. J Infect Dis. 2010;202(4):624-32. https://doi. org/10.1086/654929

PMid:20617898

11. Global Initiative for Asthma. Global Strategy for Asthma Management and Prevention. United States: Global Initiative for Asthma; 2012

12. Cox DW, Tümer Z, Roberts EA. Copper transport disorders: Wilson disease and Menkes disease. In: Fernandes $\mathrm{J}$, Saudubray JM, Van den Berghe G., editors. Inborn Metabolic Diseases. Berlin, Heidelberg: Springer; 2000. p. 384-91. https:// doi.org/10.1007/978-3-662-04285-4_33

13. Wiggins JE, Goyal M, Wharram BL, Wiggins RC. Antioxidant ceruloplasmin is expressed by glomerular parietal epithelial cells and secreted into urine in association with glomerular aging and high-calorie diet. J Am Soc Nephrol. 2006;17(5):1382-7. https:// doi.org/10.1681/asn.2005111239

PMid:16597684.

14. Baker CS, Evans TW, Haslam PL. Measurement of ceruloplasmin in the lungs of patients with acute respiratory distress syndrome: Is plasma or local production the major source? Respiration. 2000;67(5):533-8. https://doi.org/10.1159/000067469 PMid:11070458

15. Ermis B, Armutcu F, Gurel A, Kart L, Demircan N, Altin R, Demirel F. Trace elements status in children with bronchial asthma. Eur J Gen Med. 2004;1(1):4-8. https://doi.org/10.29333/ ejgm/81766

16. Vural $\mathrm{H}$, Uzun K. Serum and red blood cell antioxidant status in patients with bronchial asthma. Can Respir J. 2000;7(6):476-80. https://doi.org/10.1155/2000/907478 PMid:11121092

17. Farkhutdinov UR, Farkhutdinov SU. Efficacy of ceruloplasmin in patients with asthma. Ter Arkh. 2012;84(12):45-8. PMid:23479988

18. Van Rensen EL, Hiemstra PS, Rabe KF, Sterk PJ. Assessment of microvascular leakage via sputum induction: The role of substance $P$ and neurokinin $A$ in patients with asthma. Am J Respir Crit Care Med. 2002;165(9):1275-9. https://doi. org/10.1164/rccm.2110092 PMid:11991878

19. Yang F, Ghio AJ, Herbert DC, Weaker FJ, Walter CA, Coalson JJ Pulmonary expression of the human haptoglobin gene. Am J Respir Cell Mol Biol. 2000;23(3):277-82. https://doi.org/10.1165/ 
ajrcmb.23.3.4069

PMid:10970816

20. Kauffmann F, Frette C, Annesi I, Oryszczyn MP, Dore MF, Neukirch F. Relationships of haptoglobin level to FEV1, wheezing, bronchial hyper-responsiveness and allergy. Clin Exp Allergy. 1991;21(6):669-74. https://doi.org/10.1111/j.1365-2222.1991. tb03194.x

PMid:1777829

21. Nishioka T, Uchida $\mathrm{K}$, Meno $\mathrm{K}$, Ishii $\mathrm{T}$, Aoki $\mathrm{T}$, Imada $\mathrm{Y}$, et al. Alpha-1-antitrypsin and complement component $\mathrm{C} 7$ are involved in asthma exacerbation. Proteomics Clin Appl. 2008;2(1):46-54. https://doi.org/10.1002/prca.200780065 PMid:21136778

22. Larsen K, Macleod D, Nihlberg K, Gürcan E, Bjermer L, Marko-Varga G, et al. Specific haptoglobin expression in bronchoalveolar lavage during differentiation of circulating fibroblast progenitor cells in mild asthma. J Proteome Res. 2006;5(6):1479-83. https://doi.org/10.1021/pr050462h PMid:16739999.

23. Lamoureux A, Leclere M, Lemos K, Lefebvre J, Wagner B, Lavoie J. Systemic inflammation is present in both remission and clinical exacerbation in an equine model of severe asthma. Am J Resp Critic Care Med. 2011;183:A1322. https://doi. org/10.1164/ajrccm-conference.2011.183.1 meetingabstracts. a1322

24. Kim CK, Chung CY, Koh YY. Changes in serum haptoglobin level after allergen challenge test in asthmatic children. Allergy 1998;53(2):184-9. https://doi.org/10.1111/j.1398-9995.1998. tb03868.x

\section{PMid:9534918}

25. Koh YY, Kim YW, Park JD, Oh JW. A comparison of serum haptoglobin levels between acute exacerbation and clinical remission in asthma. Clin Exp Allergy 1996;26(10):1202-9. https://doi.org/10.1111/j.1365-2222.1996.tb00509.x PMid:8911708

26. Fröhlander $\mathrm{N}$, Stjernberg N. Association between haptoglobin groups and hereditary predisposition for bronchial asthma. Hum Hered 1989;39(1):7-11. https://doi.org/10.1159/000153824

PMid:2474487

27. Krasteva A, Perenovska P, Ivanova A, Altankova I, Bocheva T, Kisselova A. Alteration in salivary components of children with allergic asthma. Biotechnol Biotechnol Equip. 2010;24(2):18669. https://doi.org/10.2478/v10133-010-0050-2

28. Sadrzadeh SM, Bozorgmehr J. Haptoglobin phenotypes in health and disorders. Am J Clin Pathol. 2004;121(Suppl):S97-104. https://doi.org/10.1309/8glx5798y5xhq0vw PMid:15298155

29. Haenen S, Clynen E, De Vooght V, Schoofs L, Nemery B, Hoet $\mathrm{PH}$, et al. Proteome changes in auricular lymph nodes and serum after dermal sensitization to toluene diisocyanate in mice. Proteomics. 2012;12:3548-58. https://doi.org/10.1002/ pmic.201200264 PMid:23038679

30. Monferran S, Paupert J, Dauvillier S, Salles B, Muller C. The membrane form of the DNA repair protein Ku interacts at the cell surface with metalloproteinase 9. EMBO J. 2004;23:3758-68. https://doi.org/10.1038/sj.emboj.7600403 PMid:15385961

31. Araujo BB, Dolhnikoff M, Silva LF, Elliot J, Lindeman JH, Ferreira DS, et al. Extracellular matrix components and regulators in the airway smooth muscle in asthma. Eur Respir J. 2008;32(1):61-9. https://doi.org/10.1183/09031936.00147807 PMid:18321931

32. Mak JC, Ho SP, Ho AS, Law BK, Cheung AH, Ho JC, et al. Sustained elevation of systemic oxidative stress and inflammation in exacerbation and remission of asthma. ISRN Allergy. 2013;2013:561831. https://doi.org/10.1155/2013/561831 PMid:24073339

33. Hussein A, Abdel Aziz S, Ahmed A. Imbalance between serum matrix metalloproteinase- 9 and its inhibitor is associated with increased airway wall thickness in uncontrolled asthmatics. Egypt J Bronchol. 2012;6(1):37-43.

34. Muller-Eberhard U, Javid J, Liem HH, Hanstein A, Hanna M. Plasma concentrations of hemopexin, haptoglobin and heme in patients with various hemolytic diseases. Blood. 1968;32(5):811-5. https://doi.org/10.1182/blood.v32.5.811.811 PMid:5687939

35. Nielsen MJ, Moestrup SK. Receptor targeting of hemoglobin mediated by the haptoglobins: Roles beyond heme scavenging. Blood. 2009;114(4):764-71. https://doi.org/10.1182/ blood-2009-01-198309

PMid: 19380867

36. Morello N, Tonoli E, Logrand F, Fiorito V, Fagoonee S, Turco E, et al. Haemopexin affects iron distribution and ferritin expression in mouse brain. J Cell Mol Med. 2009;13(10):4192-204. https:// doi.org/10.1111/j.1582-4934.2008.00611.x PMid:19120692

37. Papanikolaou G, Pantopoulos K. Iron metabolism and toxicity. Toxicol Appl Pharmacol. 2005;202(2):199-211. PMid:15629195

38. Lee SH, Kim KH, Kim JM, Yoon SH, Kim TH, Park SW, et al Relationship between group-specific component protein and the development of asthma. Am J Respir Crit Care Med. 2011;184:528-36. https://doi.org/10.1164/rccm.201006-0951oc PMid:21169467.

39. Galez D, Dodig S, Raos M, Nogalo B. C-reactive protein in children with asthma and allergic rhinitis. Biochem Med. 2006;16(2):163-9. https://doi.org/10.11613/bm.2006.015

40. Razi E, Ehteram H, Akbari H, Chavoshi V, Razi A. Evaluation of high-sensitivity C-reactive protein in acute asthma. Tanaffos. 2012;11(1):32-7.

PMid:25191398

41. Belda J, Margarit G, Martínez C, Casan P, Rodríguez-Jerez F, Brufal $\mathrm{M}$, et al. Bronchial exudate of serum proteins during asthma attack. Arch Bronconeumol 2005;41(6):328-33. https:// doi.org/10.1016/s1579-2129(06)60232-2 PMid: 15989890

42. Büyüköztürk $S$, Gelincik $A A$, Genç $S$, Koçak $H$, Oneriyidogan $Y$, Erden S, et al. Acute phase reactants in allergic airway disease. Tohoku J Exp Med. 2004;204:209-13. https://doi.org/10.1620/ tjem.204.209 PMid: 15502420

43. Jousilahti P, Salomaa V, Hakala K, Rasi V, Vahtera E, Palosuo T. The association of sensitive systemic inflammation markers with bronchial asthma. Ann Allergy Asthma Immunol. 2002;89(4):381-5. https://doi.org/10.1016/s1081-1206(10)62039-x PMid:12392382

44. Adams BK, Cydulka RK. Asthma evaluation and management. Emerg Med Clin North Am 2003;21(2):315-30. PMid: 12793616

45. Weiss EB, Desforges JF. Oxyhemoglobin affinity in bronchial asthma: Chronic stable state, acute, and status asthmaticus. Chest. 1972;62(6):709-16. https://doi.org/10.1378/chest.62.6.709 PMid:4635420

46. Guo $\mathrm{CH}$, Liu PJ, Lin KP, Chen PC. Nutritional supplement therapy improves oxidative stress, immune response, pulmonary function, and quality of life in allergic asthma patients: An openlabel pilot study. Altern Med Rev. 2012;17(1):42-56.

PMid:22502622 
47. Hailemaryam T, Adissu W, Gedefaw L, Asres Y. Hematological profiles among asthmatic patients in Southwest Ethiopia: A comparative cross-sectional study. Hematol Transfus Int J. 2018;6(2):77-82. https://doi.org/10.15406/ htij.2018.06.00157

48. Ejaz S, Nasim F, Ashraf M, Ahmad S. Hematological and biochemical profile of patients suffering from non-atopic asthma. Insights Chest Dis. 2017;2:2. https://doi org/10.21767/2577-0578.10006

49. Ge RL, Witkowski S, Zhang Y, Alfrey C, Sivieri M, Karlsen T, et al. Determinants of erythropoietin release in response to shortterm hypobaric hypoxia. J Appl Physiol (1985). 2002;92:2361-7. https://doi.org/10.1152/japplphysiol.00684.2001

PMid:12015348 